\title{
Bone Disease Treatment Study, Major Pathways
}

\section{Jin-Yu Che and Da-Yong Lu*}

School of Life Sciences, Shanghai University, Shanghai, China

*Corresponding Author: Da-Yong Lu, School of Life Sciences, Shanghai University, Shanghai, China.
Received: February 22, 2021

Published: March 10, 2021

(C) All rights are reserved by Jin-Yu Che and

Da-Yong Lu.

\section{Abstract}

Bone disease treatment is very important worldwide. At present, drug development, surgery and instrument are major pathways for therapeutics. Until now, several pathways are widely used in the clinic. This editorial provides biomedical information and pathways for bone disease treatments.

Keywords: Osteoporosis; Drug Development; Folk Medicine; Technology; Pathology; Modern Technology; Acupuncture;

Bone-Disease

\section{Introduction}

Bone disease diagnosis, interventions and therapeutics requires new breakthroughs [1-9]. It needs different therapeutic strategies, magic bullets and paradigms [3-12]. Different aspects of pathology, therapeutics and technology are unevenly progressed. Their developmental insights are discussed in this editorial.

\section{Major pathways}

Conventional therapeutics

Drugs, surgery and assistant therapies are usual medications for bone disease treatments [13-18]. They have a long history and widely practiced in the clinic. However, these kinds of therapies loss their momentum due to lack of long-sustained financial supports and high threshold for therapeutic translations.

\section{Technology development}

The fastest path in future is technical adaptation and renovation [19]. It represents in different therapeutic modality and technical versatility [19-26].
- Drug development in low cost and toxicity (computer-aid drug design and molecular assessments)

- Digital tool in diagnosis and disease analysis

- $\quad$ Surgery assistance or automation by computers (3D printers of bone tissues, joint and others)

- Supportive techniques (movement assistance and prosthetic limbs)

- Artificial intelligence

- New materials (inorganic, organic and bio-materials for dead bone replacement).

\section{Traditional chinese medicine (TCM)}

Folk medicine still has its territories in bone disease treatments [27], such as acupuncture [28], herbal plaster and medicine $[29,30]$. By these traditional medications, clinical orthopedic treatments will be improved without the necessity of high costs of treatments and nursery. 
Major therapeutics in China [27-30]

- Massage

- Acupuncture

- Herbal plaster

- Herbal medicine

\section{Conclusion}

There are many diagnostic and therapeutic options and approaches in bone study. With the rapid development of diagnostic and therapeutic versatility for bone diseases, we should expect new surprise and breakthroughs in the future.

\section{Bibliography}

1. Melton J. "Hip fracture; a worldwide problem today and tomorrow". Bone 14 (1993): S1-8.

2. Choudhary D and Alam A. "Anti-osteoporotic activity of bioactive compounds from Iris germanica targeting NK-Kappa B". EC Pharmacology and Toxicology 6.8 (2018): 665-678

3. Lu DY and Shen Y. "Bone surgery, tissue and function repairs". EC Orthopaedics 11.3 (2020): 1-2.

4. Zweedijk R., et al. "Scoliosis and osteopathy". Acta Scientific Orthopaedics 3.9 (2020): 30-43.

5. Lu DY and Che JY. "Bone disease treatment, an editorial". EC Orthopeadics 11.8 (2020): 143-145.

6. Lu DY., et al. "Bone disease recovery strategies, An overview". EC Orthopaedics 10.1 (2019): 1-3.

7. Koleva IB and Yoshinov B. "Rehabilitation as an essential element in the clinical practice of orthopaedics and traumatology". Acta Scientific Orthopaedics 3.9 (2020): 44-46.

8. Lu DY., et al. "Osteoporosis treatments for old people". EC Orthopeadics 10.5 (2019): 278-280

9. Che JY and Lu DY. "Bone disease treatment, future direction". EC Pharmacology and Toxicology 9.1 (2021): 7-8.

10. Lu DY., et al. "Nursery education in schools, significance for career". Biomedical Research and Reviews 2.2 (2019): 113.
11. Lu DY., et al. "Patient's care and nursery in different diseases". Hospice and Palliative Medicine International Journal 3.1 (2019): 28-30.

12. Lu DY., et al. "Patient's care and nursery in modern medicine". Nursery Practice and Health Care 1.1 (2019): 101.

13. Araujo JL. "The role of the orthopedic surgeon in preventing low back pain chronification". EC Orthopaedics 9.12 (2018): 809-812

14. Negm SH. "The possible protective role of powder cuttlefish bone, crab shell and eggshell on osteoporotic rats". Journal of Food and Diary Science 9.10 (2018): 111-121.

15. Mobasheri A and Shakbael M. "Osteogenic effects of resveratrol in vitro: potential for the prevention and treatment of osteoporosis". Annals of the New York Academy of Sciences 1290 (2013): 59-66.

16. Madrv H., et al. "Scaffold-mediated gene delivery for osteochondral repair". Pharmaceutics 12 (2020): 930.

17. Lu DY., et al. "Bone surgery with bone anatomy analysis". EC Clinical Experimental Anatomy 3.1 (2020): 1-4.

18. Moore N and Slater GL. "Surgical technique update: Slater modification of minimally invasive brostrom reconstruction". EC Orthopaedics 10.5 (2019): 308-314.

19. Lu DY and Che JY. "Bone disease treatments, technical advances". EC Orthopeadics 11.10 (2020): 1-3.

20. Lu DY., et al. "3 D print for bone replacement and design". EC Orthopaedics (2019): 1-2.

21. Harsini SM and Oryan A. "Bone grafting and the materials for using in orthopaedics". EC Orthopaedics 9.12 (2018): 822-833

22. Lu DY., et al. "Bone disease treatments, math-therapeutic modality". EC Orthopaedics 10.3 (2019): 140-143.

23. Muthuraman A., et al. "Integration of artificial intelligence in pharmacological research with deep and machine learning process". EC Pharmacology and Toxicology 7.11 (2019): 56-61.

24. Freedman DH. "Hunting for new drugs with AI". Nature 576 (2019): s49-s53. 
25. Lu DY and Che JY. "Communication platform for reducing foot or limb amputation”. EC Emergency Medicine and Clinical Care 4.6 (2020): 74 .

26. Borrego-Gonzalez S., et al. "Sponge-like processed D-periodic self-assembled atelocollagen supports bone formation in vivo". Materials Science and Engineering C 120 (2021).

27. Leung PC. "Traditional Chinese medicine in orthopaedicsproblems and future direction". Open Journal of Therapy and Rehabilitation 2.1 (2014): 1-4.

28. Che JY and Lu DY. "Acupuncture for bone disease treatment". EC Orthopaedics 12.1 (2021): 15-16.

29. Che JY and Lu DY. "Herbal plaster for bone disease treatments". Acta Scientific Orthopaedics 4.1 (2021): 1-2.

30. Lu DY and Lu TR. "Herbal medicine in new era". Hospice Palliative Medicine International 3.4 (2019): 125-130.

\section{Assets from publication with us}

- Prompt Acknowledgement after receiving the article

- Thorough Double blinded peer review

- Rapid Publication

- Issue of Publication Certificate

- High visibility of your Published work

Website: www.actascientific.com/

Submit Article: www.actascientific.com/submission.php

Email us: editor@actascientific.com

Contact us: +919182824667 